\title{
IN VIVO AND IN VITRO INVESTIGATIONS OF PHARMACOLOGICAL POTENTIALS OF CASSIA OBTUSIFOLIA PLANT
}

\begin{abstract}
KEWATKAR SM ${ }^{1 *}$, PAITHANKAR VV ${ }^{2}$, BHUJBAL SS ${ }^{3}$, JAIN SP ${ }^{1}$, NAGORE DH ${ }^{4}$
${ }^{1}$ Department of Pharmacognosy, Rajarshi Shahu College of Pharmacy, Buldana, Maharashtra, India. ${ }^{2}$ Department of Pharmacology, Vidyabharti College of Pharmacy, Amravati, Maharashtra, India. ${ }^{3}$ Dr. D.Y. Patil Institute of Pharmaceutical Sciences and Research, PimpriChinchwad, Maharashtra, India. ${ }^{4}$ Department of Pharmacy, Shri Jagdishprasad Jhabarmal Tibrewala University, Jhunjhunu, Rajasthan, India. Email: kewatkar.shailesh@gmail.com
\end{abstract}

Received: 14 December 2019, Revised and Accepted: 11 January 2020

\section{ABSTRACT}

Objectives: Cassia obtusifolia L. belonging to the Family Caesalpiniaceae, proposed to have abundant pharmacological potential and widely consumed as laxative, diuretic, and stomachic. The aim of the present research was to study the anti-inflammatory, analgesic, antipyretic, and antioxidant potentials of $C$. obtusifolia plant.

Methods: Various acute and chronic animal models such as Carrageenan-induced paw edema, tail immersion method, acetic acid-induced writhing, and in vitro methods were used to study the profound pharmacological and antioxidant potentials.

Results: The results for pharmacological study were statistically analyzed by one-way ANOVA followed by Dunnett's multiple comparisons using INTA software.

Conclusion: The present study reveals that C. obtusifolia possesses comparable anti-inflammatory, analgesic, antipyretic, and antioxidant potential.

Keywords: Cassia obtusifolia, Anti-inflammatory, Antioxidant, Carrageenan, Antipyretic.

(c) 2020 The Authors. Published by Innovare Academic Sciences Pvt Ltd. This is an open access article under the CC BY license (http://creativecommons. org/licenses/by/4. 0/) DOI: http://dx.doi.org/10.22159/ajpcr.2020.v13i3.36623

\section{INTRODUCTION}

Drugs presently used for the management of pain and inflammatory conditions are either narcotics, for example, opioids or nonnarcotics, for example, salicylates and corticosteroids, and for example, hydrocortisone. Being synthetically designed these drugs possess well-recognized side and toxic effects. On the contrary, many medicines from plant origin had been used for long time. Exploring the healing power of plants, people from centuries have been trying to alleviate and treat diseases with different plant extracts and formulations [1]. Plants represent a large intact source of structurally novel compounds that might serve as the basis for the development of novel drugs. Screening of the plants for their biological activity merely depends on their chemotaxonomic investigation or ethnobotanical knowledge for a particular disease. Identification of a specific compound against a specific disease is a challenging extensive process [2]. Literature research for several medicinal plants possesses active constituents with significant antiinflammatory and analgesic activities.

Cassia obtusifolia L. belonging to Caesalpiniaceae family, also known as sicklepod is extensively used as a traditional medicine [3]. The foremost active components of $C$. obtusifolia include anthraquinones, naphthopyrones, and lactones which are assumed to possess various medicinal potentials. The plant is also widely consumed as laxative, diuretic, stomachic, and digestive aid [4].

Hence, an attempt has been made to conduct studies for ascertaining anti-inflammatory, antipyretic, and analgesic potential of the medicinal plant $C$. obtusifolia using different animal models. Different in vitro methods were also used to study the antioxidant potential of C. obtusifolia plant.

\section{METHODS}

\section{Chemicals}

All AR grade solvents such as ethanol, ethyl acetate, sodium carbonate, sodium phosphate, hydrogen peroxide, and trichloroacetic acid were procured from Merck Life Science Private Ltd, Vikhroli (East), Mumbai, India. Gallic acid, Folin-Ciocalteu reagent;1, and 1-diphenyl2-picrylhydrazyl (DPPH) were procured from SD-Fine Chem Ltd., Fischer Scientific Pvt. Ltd, Pune, India, and HiMedia Lab. Ltd., Mumbai, respectively. Marketed tablet formulations of indomethacin, pentazocine, and paracetamol were used as standard drugs that were procured from the local market.

\section{Procurement and authentication of plant}

The leaves of the plant were collected from fields of Sant Tukaram Nagar, Pimpri, Pune, and authenticated by the Botanical Survey of India, Pune, and were given the voucher specimen number SMK-1.

\section{Extraction procedure}

Leaves of C. obtusifolia Linn. (2 kg) were dried under shade and grinded to get the coarse powdered material. The extraction of the powdered leaves was carried out by the maceration (water) process. Then, the solution was filtered and to this filtrate, alcohol was added to get precipitate of the polysaccharides. Then, the resulting solution was filtered and the filtrate was evaporated to $1 / 4^{\text {th }}$ of the total volume. After evaporating $1 / 4^{\text {th }}$ of the total volume of the solution, it was successively extracted with ethyl acetate. The ethyl acetate extract was evaporated to get the brownishyellow colored flavonoid-rich fraction of C. obtusifolia Linn. (FRCO) $(1 \% \mathrm{w} / \mathrm{w})$ which gave a positive response to the Shinoda test for the flavonoids [5-7]. 


\section{Pharmacological screening}

The pharmacological screening was performed on Swiss albino mice of either sex weighing 18-25 g and Wistar rats of either sex weighing 150-200 g at Padm. Dr. D.Y. Patil Institute of Pharmaceutical Sciences and Research, Pimpri, Pune. The animals were kept in the departmental animal house in well cross-ventilated room at $27 \pm 2^{\circ} \mathrm{C}$, light and dark cycles of $12 \mathrm{~h}$, respectively, for 1 week before and during the experiments. All the animals of either sex were housed in groups of five under standard laboratory conditions with free access to a standard pellet diet and water ad libitum. All experiments were conducted in accordance with the guidelines of the local animal ethical committee (Registration no. 198/CPCSEA).

\section{Preparation of test solutions}

FRCO was accurately weighed and suspended in distilled water using 1\% gum acacia. Other standard solutions such as indomethacin, pentazocine, and paracetamol were suspended in normal saline solution.

\section{Acute toxicity study}

Acute toxicity study was carried out on Swiss albino mice which were divided into three groups, each containing six animals. Group I animals were treated with vehicle (1\% gum acacia) and were served as control group, while the Groups II and III animals were administered with aqueous extract of $C$. obtusifolia and flavonoid-rich FRCO orally in varying doses of $0.50,0.75,1.00,1.25,1.50,1.75,2.00$, and $2.50 \mathrm{~g} / \mathrm{kg}$, respectively. The animals were continuously observed for $72 \mathrm{~h}$ to detect changes in the autonomic or behavioral responses such as alertness, spontaneous activity, irritability, and urination. Any mortality during experimentation and in the following 7 days was also recorded [8].

\section{Anti-inflammatory activity}

Anti-inflammatory activity was studied using acute and chronic antiinflammatory models such as carrageenan-induced paw edema, acetic acid-induced vascular permeability, and cotton pellet-induced granuloma.

\section{Carrageenan-induced paw edema}

The acute hind paw edema was produced by injecting $0.1 \mathrm{ml}$ of carrageenan ( $1 \%$ suspension in saline) locally into the subplantar aponeurosis of the right hind paw of rats. Animals were divided into five groups, six rats per group. FRCO was administered orally at different doses $(50,100$, and $200 \mathrm{mg} / \mathrm{kg})$ along with the standard drug indomethacin (10 mg/kg, p.o.) and 1\% acacia solution (p.o.). FRCO and indomethacin were administered $1 \mathrm{~h}$ before injection of carrageenan in the right hind paw subplantar of each rat. The rat pedal volume up to the ankle joint was measured using plethysmometer (Ugo Basile, 7140, Italy) at $0,1,2,3,4,5,6$, and $24 \mathrm{~h}$ after the injection of carrageenan and the percent inhibition was calculated using the formula;

$$
\text { Percent inhibition }=\mathrm{Vc}-\mathrm{Vt} / \mathrm{Vc} \times 100
$$

Where Vc and Vt represent the mean increase in paw volume in control and treated groups, respectively [9].

\section{Acetic acid-induced vascular permeability}

The mice were intravenously injected with $10 \mathrm{ml} / \mathrm{kg}$ of $1 \%$ Evans Blue dye solution in saline, followed by intraperitoneal injection of $10 \mathrm{ml} / \mathrm{kg}$ of $0.7 \%$ acetic acid. The FRCO $(50 \mathrm{mg} / \mathrm{kg}, 100 \mathrm{mg} / \mathrm{kg}$, and $200 \mathrm{mg} / \mathrm{kg}$ ), indomethacin (10 mg/kg), and 1\% acacia solution (p.o.) were administered orally $1 \mathrm{~h}$ before the injection of Evans blue. Twenty minutes after the injection of acetic acid, the mice were sacrificed by cervical dislocation. Peritoneal fluids were collected by washing with $5 \mathrm{ml}$ of normal saline and then centrifuged at $3000 \mathrm{rpm}$ for $15 \mathrm{~min}$. The absorbance of the supernatant was read at $590 \mathrm{~nm}$ using a spectrophotometer (Shimadzu 7140) [10-12].

\section{Cotton pellet-induced granuloma}

The test samples, indomethacin, and 1\% acacia solution in distilled water were administered orally once daily for 7 days. Sterilized cotton pellet weighing $20 \mathrm{mg}$ were put subcutaneously into the groin region of rats on the $1^{\text {st }}$ day. The animals were sacrificed on the $8^{\text {th }}$ day. The pellets, which by then were surrounded by granuloma tissue, and the thymus were dissected out carefully and dried at $600^{\circ} \mathrm{C}$ to a constant weight. The wet weight and dry weight were determined. The percentage of inhibition was expressed by comparing the mean weight in the test groups with that in the control group.

\section{Analgesic activity}

Analgesic activity was studied using four different models, such as acetic acid-induced writhing, hot plate method, formalin test, and tail immersion test $[11,13]$.

\section{Acetic acid-induced writhing test}

In the writhing test, male mice were divided into five groups. The mice were treated with $0.6 \%$ acetic acid solution in normal saline injected intraperitoneally at a dose of $10 \mathrm{ml} / \mathrm{kg}$. The numbers of writhes were counted starting from $5 \mathrm{~min}$ after injection that lasted for $15 \mathrm{~min}$. The response consisted of abdominal wall contractions, pelvic rotation, followed by hind limb stretches. The test samples, indomethacin, and $1 \%$ acacia solution (p.o.) were administered orally $1 \mathrm{~h}$ before acetic acid injection. The percentage of analgesic activity was calculated as follows:

Percentage analgesic activity $=\mathrm{Nc}-\mathrm{Nt} / \mathrm{Nc} \times 100$

Where, Nc is the average number of stretches of the control group, Nt is the average number of stretches of the test drug group $[11,14]$

\section{Hot plate method}

The hot plate test was carried out at a fixed temperature of $55 \pm 5^{\circ} \mathrm{C}$. The reaction consisted of paw licking and jumping. The time in seconds between the platform and reaction was recorded as the response latency. The mice exhibiting latency time $>30 \mathrm{~s}$ or $<5 \mathrm{~s}$ were excluded from the study. The latency time was determined at $0 \mathrm{~min}, 30 \mathrm{~min}, 60 \mathrm{~min}, 90 \mathrm{~min}$, and $120 \mathrm{~min}$ after administration of the test samples, pentazocine $(10 \mathrm{mg} / \mathrm{kg}$ i.p.), and $1 \%$ acacia solution (p.o.) $[10,14,15]$

\section{Formalin test}

Albino mice of either sex were divided into five groups. Group I considered as normal control received orally with the vehicle $1 \%$ gum acacia, Group II with standard indomethacin ( $5 \mathrm{mg} / \mathrm{kg}$, i.p), Groups III, IV, and $V$ were given orally with different doses, i.e., $50 \mathrm{mg} / \mathrm{kg}, 100 \mathrm{mg} / \mathrm{kg}$, and $200 \mathrm{mg} / \mathrm{kg}$ of FRCO. One hour after the above treatment, $20 \mu \mathrm{l}$ of $2.5 \%$ formalin was injected into the subplantar region of each animal. Duration of paw lickings was monitored for 0-5 min (Early phase) and at 20-25 min (Late phase) after formalin challenge [16].

\section{Tail immersion test}

The basal reaction time of each mouse was determined using tailwithdrawal response when one-third of the tail was immersed in a water bath at $51 \pm 1^{\circ} \mathrm{C}$. Mice with basal reaction time between 5 and $10 \mathrm{~s}$ were selected $24 \mathrm{~h}$ before the test. The animals were treated with gum acacia 1\%, pentazocine (10 mg/kg, i.p.), and FRCO (50, 100 and $200 \mathrm{mg} / \mathrm{kg}$ p.o.) and $30,60,90$, and $120 \mathrm{~min}$ later the reaction time was evaluated. The cutoff time for immersion was $180 \mathrm{~s}$ [17].

\section{Antipyretic activity}

The antipyretic property of FRCO was tested in rats in which hyperthermia was introduced. Initial rectal temperature was recorded using Digital Tele Thermometer (Model No. 461E, INCO, Ambala, India). Rats were made hyperthermic by subcutaneous injection of $20 \%$ yeast suspension at the dose of $1 \mathrm{ml} / 100 \mathrm{~g}$ of body weight. When rectal temperature was at peak (16 h after injection of yeast suspension), the rectal temperature was again recorded. Test and control drug was given orally. After $1 \mathrm{~h}$, temperature was recorded followed by $1 \mathrm{~h}$ interval for consecutive $5 \mathrm{~h}$. 
In vitro antioxidant activity

In vitro antioxidant activity was studied by total phenolic content, DPPH free radical scavenging activity, hydrogen peroxide assay, and reducing power assay.

\section{Total phenolic content}

$2 \mathrm{ml}$ sample solution, $10 \mathrm{ml}$ water, and $2 \mathrm{ml}$ Folin-Ciocalteu reagent were mixed up and volume was made up to $25 \mathrm{ml}$ by adding sodium carbonate solution. After incubation, the absorbance of the solution was measured at $750 \mathrm{~nm}$. Instead of sample solution, gallic acid was added and same procedure was repeated for the standard gallic acid solution. From the stock solution of gallic acid, different concentrations were prepared $250,500,750,1000$, and $1250 \mu \mathrm{l}$ and calibration curve was plotted. Line equation obtains from the calibration curve was used for determining $\%$ of total polyphenols with that of gallic acid $[18,19]$.

\section{DPPH free radical scavenging activity}

$1 \mathrm{ml}$ of different concentrations of extract solution were taken in different vials. To this, $5 \mathrm{ml}$ of methanolic solution of DPPH was added, shaken well and mixture was incubated at $37^{\circ} \mathrm{C}$ for $20 \mathrm{~min}$. Absorbance was measured against methanol as a blank at $517 \mathrm{~nm}$ and absorbance of DPPH was taken as control. Percent antiradical activity was calculated using the following formula [20]:

$$
\% \text { Scavenging activity }=0 D_{\text {Control }}-O D_{\text {Test }} \text { sample } / O D_{\text {Control }} \times 100
$$

\section{Hydrogen peroxide assay}

$1 \mathrm{ml}$ different concentrations of extract solution were taken in different vials. Different concentrations $(25-200 \mu \mathrm{g} / \mathrm{ml})$ of FRCO were added to $0.6 \mathrm{ml}$ of $\mathrm{H}_{2} \mathrm{O}_{2} 40 \mathrm{mM}$ ). The absorbance of the solution was read at $230 \mathrm{~nm}$ after $10 \mathrm{~min}$ against a blank containing FRCO in phosphatebuffered without $\mathrm{H}_{2} \mathrm{O}_{2}$. The concentration of $\mathrm{H}_{2} \mathrm{O}_{2}$ was determined spectrophotometrically at $230 \mathrm{~nm}$. The percent scavenging of $\mathrm{H}_{2} \mathrm{O}_{2}$ by FRCO was calculated using the formula [21]:

$\%$ Scavenging = Absorbance of control-Absorbance of sample/ Absorbance of control $\times 100$

\section{Reducing power assay}

$1 \mathrm{ml}$ of FRCO (dilution) was mixed with $1 \mathrm{ml}$ of 0.2 M sodium phosphatebuffered ( $\mathrm{pH} \mathrm{6.6)}$ and $1 \mathrm{ml}$ of $1 \%$ potassium ferricyanide. The reaction mixtures were incubated 50 OC for $20 \mathrm{~min}$. Then, $1 \mathrm{ml}$ of $10 \%$ trichloroacetic acid was added into the reaction mixture. The mixtures were then centrifuged for $10 \mathrm{~min}$ at room temperature. The supernatant obtained $(1 \mathrm{ml})$ was added with $1 \mathrm{ml}$ of distilled water and $200 \mu \mathrm{l}$ of $0.1 \% \mathrm{FeCl}_{3}$. The blank was prepared in the same manner as the samples except that $1 \%$ potassium ferricyanide was replaced by distilled water. The absorbance of the reaction mixture was measured at $700 \mathrm{~nm}$. The reducing power was expressed using the following formula [22].

$$
\% \text { Scavenging }=A_{0}-A_{1} / A_{0} \times 100
$$

Where $A_{0}$ is the absorbance of the blank and $A_{1}$ is the absorbance of test.

\section{Statistical analysis}

Values were presented as mean \pm SEM. Statistical analysis was performed by one-way ANOVA followed by Dunnett's multiple comparison using INTA software. The level of significance was set as $p<0.05$ and $p<0.01$.

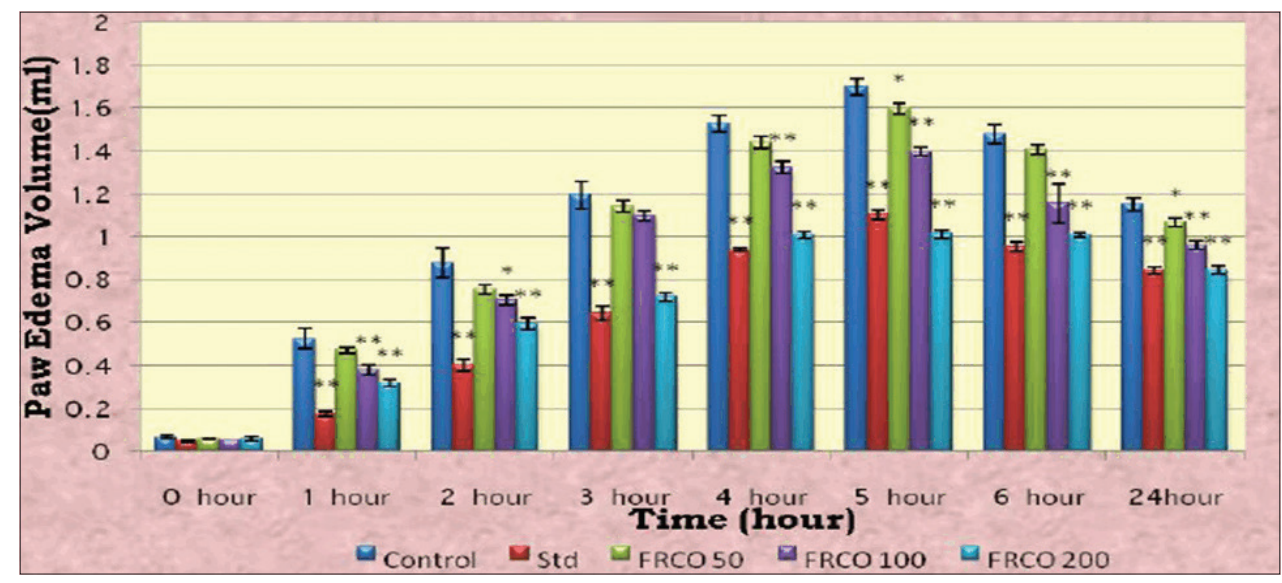

Fig. 1: Effects of FRCO on carrageenan-induced hind paw edema. ${ }^{*} \mathbf{p}<0.05,{ }^{* *} \mathbf{p}<0.01$, compared with the control group (ANOVA followed by Dunnett's test). Where, $\mathrm{N}=5$ Mean \pm SEM $=$ Mean \pm Standard error of mean

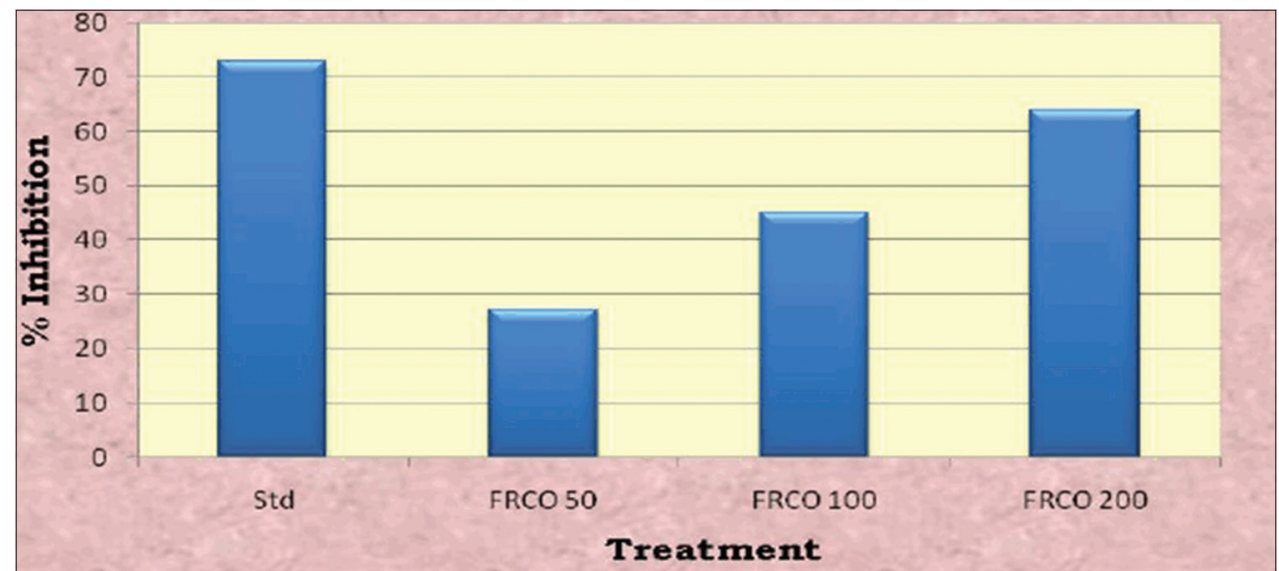

Fig. 2: Effect of FRCO on acetic acid-induced vascular permeability in mice. Where, $\mathbf{N}=5 \mathrm{Mean} \pm \mathrm{SEM}=\mathrm{Mean} \pm \mathrm{Standard}$ error of mean 


\section{RESULTS AND DISCUSSION}

\section{Acute toxicity study}

There was no toxic reaction or mortality observed. Flavonoid-rich fraction was found to be safe up to $2000 \mathrm{mg} / \mathrm{kg}$ p.o. Thus, based on the results of preliminary toxicity testing of the doses of 50,100 , and $200 \mathrm{mg} / \mathrm{kg}$ p.o. were chosen for further experiments.

\section{Anti-inflammatory activity}

Effect of FRCO on carrageenan-induced hind paw edema in rats

In carrageenan-induced hind paw edema, FRCO (50, 100, and $200 \mathrm{mg} / \mathrm{kg}$, p.o.) reduced carrageenan-induced edema formation significantly at $1^{\text {st }}, 2^{\text {nd }}, 5^{\text {th }}$, and $6^{\text {th }} \mathrm{h}$. A significant inhibition in edema formation was observed by both FRCO and indomethacin at $24^{\text {th }} \mathrm{h}$ (Fig. 1)

\section{Effects of FRCO on acetic acid-induced vascular permeability}

The FRCO treatmentinhibited acetic acid-induced vascular permeability, and the same was reflected in increased leakage of dye. The amount of dye leakage was significantly $(\mathrm{p}<0.01)$ reduced by all the doses $(50,100$, and $200 \mathrm{mg} / \mathrm{kg}$, p.o.) of extract. The dose of indomethacin (10 mg/kg p.o.) prevented significantly dye leakage and the effect was greater than the FRCO (Table 1 and Fig. 2).

\section{Effects of FRCO on cotton pellet-induced granuloma}

In cotton pellet-induced granuloma in rats, the FRCO treatment orally inhibited the inflammatory effect on both the phases of inflammation and effect was found to be dose-related. Indomethacin $(10 \mathrm{mg} / \mathrm{kg}$ p.o.) treatment also elicited inhibitory effects on both exudate and granulation phases of inflammation. The indomethacin effect was greater than the FRCO (Fig. 3).

\section{Analgesic activity}

Effects of FRCO on acetic acid-induced writhing test

The FRCO at the dose 50, 100, and $200 \mathrm{mg} / \mathrm{kg}$, p.o. inhibited acetic acidinduced writhing in mice. Indomethacin showed greater inhibition in acetic acid-induced writhing as compared to FRCO (Table 2 and Fig. 4).

\section{Effects of FRCO on hot plate method}

The FRCO at the dose 50, 100, and $200 \mathrm{mg} / \mathrm{kg}$, p.o. significantly inhibited the latency period. Pentazocine showed greater inhibition in the hot plate method model of analgesic as compared to FRCO (Table 3).

\section{Effects of FRCO on the formalin test method}

In the formalin test method, the FRCO treatment orally inhibited both phases, i.e., early and late phase and effect was found to be dose related. Indomethacin $5 \mathrm{mg} / \mathrm{kg}$ i.p shows an inhibitory reaction greater than the FRCO (Fig. 5)

\section{Effects of FRCO on tail-flick test}

The ability of FRCO to induce the central analgesia was evaluated by temperature-based tests. As per the results, in tail-flick test the FRCO treatment orally increase the time duration of flicking of tail when

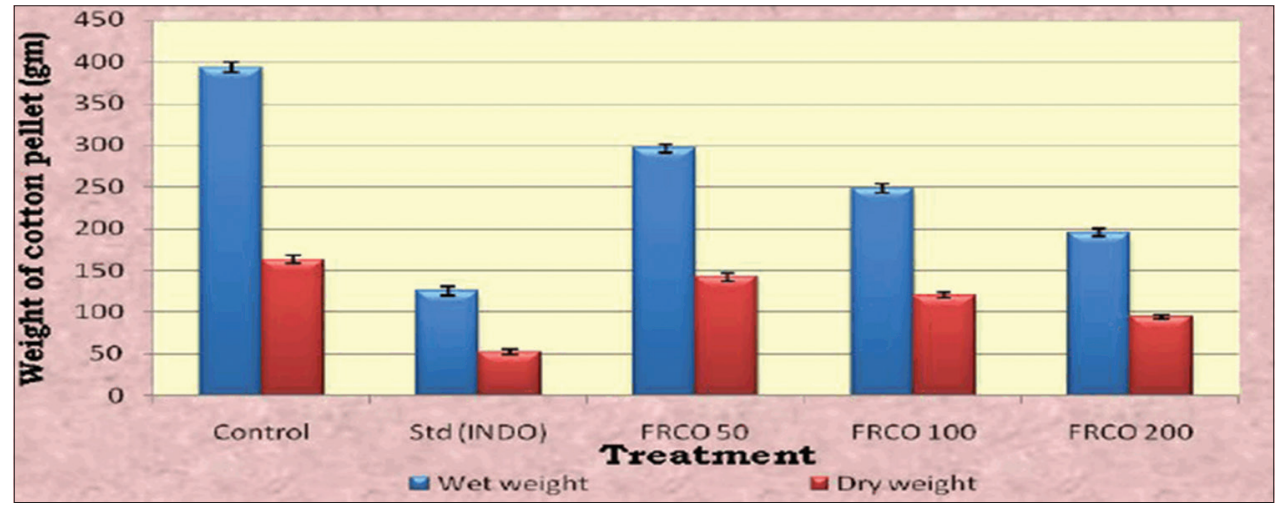

Fig. 3: Effect of FRCO on cotton pellet-induced granuloma in rats. Where, $N=5$ Mean \pm SEM $=$ Mean \pm Standard error of mean

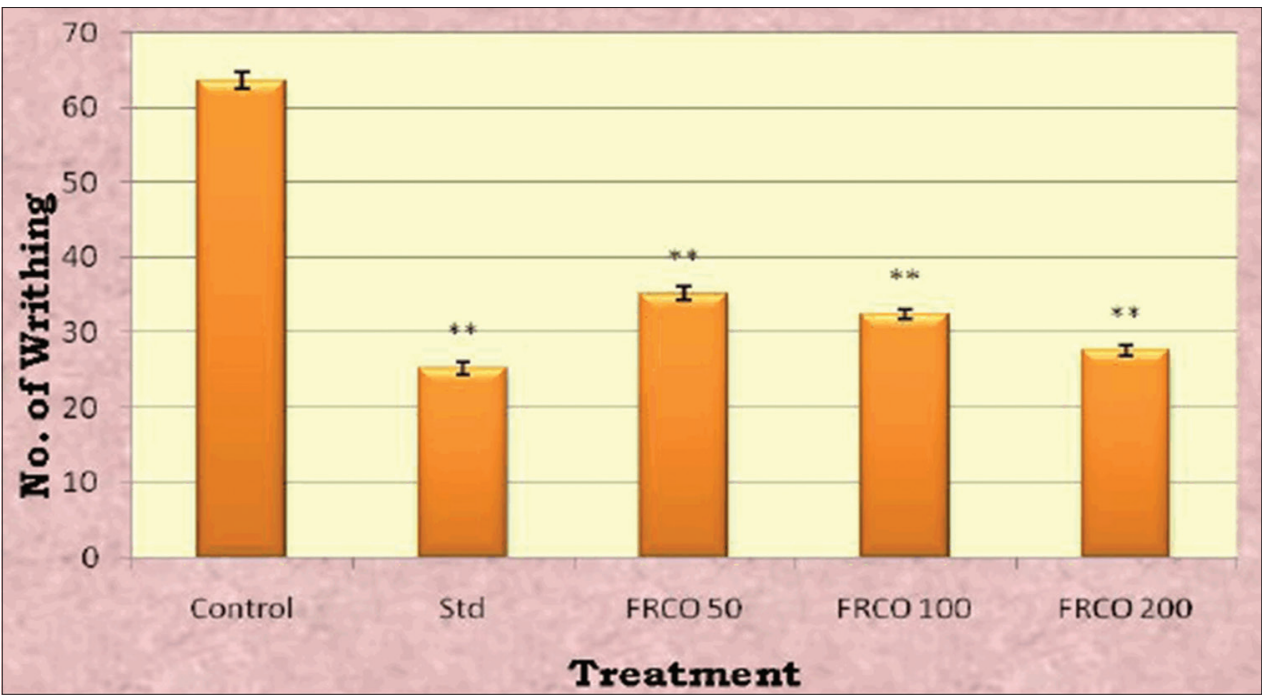

Fig. 4: Effect of FRCO on acetic acid-induced writhing test. ${ }^{*} \mathrm{p}<0.05,{ }^{* *} \mathrm{p}<0.01$, compared with the control group (ANOVA followed by Dunnett's test). Where, $\mathbf{N}=5$ Mean \pm SEM $=$ Mean \pm Standard error of mean 
Table 1: Effect of FRCO on acetic acid-induced vascular permeability in mice

\begin{tabular}{llll}
\hline $\begin{array}{l}\text { Name of } \\
\text { groups }\end{array}$ & OD & $\begin{array}{l}\text { Amount of dye } \\
\text { leakage }\end{array}$ & \% Inhibition \\
\hline Control & $0.1101 \pm 0.001$ & $26.25 \mu \mathrm{g} / \mathrm{ml}$ & - \\
Std. (INDO) & $0.0321 \pm 0.007$ & $07.75 \mu \mathrm{g} / \mathrm{ml}$ & 73 \\
FRCO 50 & $0.0835 \pm 0.001$ & $20.12 \mu \mathrm{g} / \mathrm{ml}$ & 27 \\
FRCO 100 & $0.0605 \pm 0.002$ & $14.62 \mu \mathrm{g} / \mathrm{ml}$ & 45 \\
FRCO 200 & $0.0450 \pm 0.003$ & $10.87 \mu \mathrm{g} / \mathrm{ml}$ & 64 \\
\hline
\end{tabular}

OD: Optical density, FRCO: Flavonoid-rich fraction of $C$. obtusifolia Linn. Where $\mathrm{N}=5$ Mean \pm SEM=Mean \pm Standard error of mean

Table 2: \% Inhibition of FRCO on acetic acid-induced writhing test

\begin{tabular}{lllll}
\hline S. No. & Group & $\begin{array}{l}\text { Dose } \\
\text { (mg/kg) }\end{array}$ & $\begin{array}{l}\text { Number of } \\
\text { writhing }\end{array}$ & \% inhibition \\
\hline 1. & Control & -- & $63.6 \pm 1.030$ & -- \\
2. & Std. (INDO) & 10 & $25.2 \pm 0.860 * *$ & 60 \\
3. & FRCO 50 & 50 & $35.2 \pm 0.969 * *$ & 44 \\
4. & FRCO 100 & 100 & $32.4 \pm 0.678^{* *}$ & 49 \\
5. & FRCO 200 & 200 & $27.6 \pm 0.748 * *$ & 56 \\
\hline
\end{tabular}

${ }^{*} \mathrm{p}<0.05,{ }^{* *} \mathrm{p}<0.01$, compared with control group (ANOVA followed by Dunnett's test). Where, $\mathrm{N}=5$, Mean \pm SEM=Mean \pm Standard error of mean deep into the water bath. The pretreated animals increased the basal reaction time. At high doses $(200 \mathrm{mg} / \mathrm{kg})$ of FRCO and pentazocine (10 $\mathrm{mg} / \mathrm{kg}$ i.p) increase the percentage reaction time effectively. Pentazocine (10 mg/kg i.p) shows an inhibitory reaction greater than the FRCO (Fig. 6)

\section{Antipyretic activity}

Effect of FRCO on pyrexia-induced by brewer's yeast in rats

In the antipyretic activity, FRCO at the dose level of 50, 100, and $200 \mathrm{mg} / \mathrm{kg}$ significantly reduced the fever induced by the brewer's yeast in rats. FRCO reduced the fever particularly at $5^{\text {th }}$ and $6^{\text {th }} \mathrm{h}$ in dosedependent manner, whereas paracetamol reduced the fever right from the $2^{\text {nd }}$ to the $6^{\text {th }} \mathrm{h}$ (Tables 4 and 5).

\section{In vitro antioxidant activity}

Total phenolic content

Total polyphenolic content was observed to be $31.50 \mathrm{mg} / \mathrm{g}$ of gallic acid. It was observed that gallic acid being the major component of ethanolic extract and was mainly responsible for antioxidant activity.

\section{DPPH free radical scavenging activity}

In DPPH radical scavenging activity, FRCO and ascorbic acid showed significant DPPH free radical scavenging activity at different concentrations $(50,100,150,200$, and $250 \mu \mathrm{g} / \mathrm{ml})$ in dose-dependent manner. $\mathrm{IC}_{50}$ value was found to be 137 and $200 \mathrm{~g} / \mathrm{ml}$ for ascorbic acid and FRCO, respectively (Table 6 and Fig. 7).

Table 3: Effect of FRCO in hot plate method

\begin{tabular}{|c|c|c|c|c|c|c|}
\hline \multirow[t]{2}{*}{ Group } & \multirow[t]{2}{*}{ Dose mg/kg } & \multicolumn{5}{|l|}{ Time (h) } \\
\hline & & $\mathbf{0 ~ h}$ & $0.5 \mathrm{~h}$ & $1 \mathrm{~h}$ & $1.5 \mathrm{~h}$ & $2 \mathrm{~h}$ \\
\hline Control & - & $6.56 \pm 0.060$ & $6.42 \pm 0.037$ & $6.7 \pm 0.044$ & $6.62 \pm 0.048$ & $6.7 \pm 0.044$ \\
\hline Std(PENT) & 10 & $6.62 \pm 0.048$ & $14.08 \pm 0.080^{* *}$ & $15.98 \pm 0.058^{* *}$ & $16.74 \pm 0.067^{* *}$ & $15.96 \pm 0.050 * *$ \\
\hline FRCO 50 & 50 & $6.7 \pm 0.044$ & $8.68 \pm 0.058^{* *}$ & $9.4 \pm 0.063^{* *}$ & $11.8 \pm 0.054^{* *}$ & $11.12 \pm 0.066^{* *}$ \\
\hline FRCO 100 & 100 & $6.18 \pm 0.048$ & $9.2 \pm 0.044^{* *}$ & $11.2 \pm 0.054^{* *}$ & $12.7 \pm 0.083^{* *}$ & $12.2 \pm 0.044^{* *}$ \\
\hline FRCO 200 & 200 & $6.44 \pm 0.040$ & $9.74 \pm 0.074^{* *}$ & $12.04 \pm 0.081^{* *}$ & $13.16 \pm 0.074^{* *}$ & $12.38 \pm 0.086^{* *}$ \\
\hline
\end{tabular}

${ }^{*} \mathrm{p}<0.05,{ }^{* *} \mathrm{p}<0.01$, compared with control group (ANOVA followed by Dunnett's test). Where, $\mathrm{N}=5 \mathrm{Mean} \pm \mathrm{SEM}=\mathrm{Mean} \pm$ Standard error of mean

Table 4: Effect of FRCO on pyrexia-induced by brewer's yeast in rats

\begin{tabular}{|c|c|c|c|c|c|c|c|}
\hline \multirow[t]{2}{*}{ Group } & \multirow[t]{2}{*}{ Dose $\mathrm{mg} / \mathrm{kg}$} & \multicolumn{6}{|c|}{ Temperature $\left({ }^{\circ} \mathrm{C}\right)($ Mean \pm SEM $)$} \\
\hline & & $1 \mathrm{~h}$ & $2 \mathrm{~h}$ & $3 \mathbf{h}$ & $4 \mathrm{~h}$ & $5 \mathbf{h}$ & $6 \mathrm{~h}$ \\
\hline Vehicle & - & $37.34 \pm 0.097$ & $37.42 \pm 0.058$ & $37.48 \pm 0.073$ & $37.40 \pm 0.054$ & $37.52 \pm 0.086$ & $37.5 \pm 0.031$ \\
\hline Control & - & $39.42 \pm 0.073$ & $39.6 \pm 0.044$ & $39.44 \pm 0.067$ & $39.28 \pm 0.066$ & $38.06 \pm 0.050$ & $39.08 \pm 0.050$ \\
\hline Std. (PARA) & 150 & $39.2 \pm 0.077$ & $38.9 \pm 0.070$ & $38.68 \pm 0.037$ & $38.34 \pm 0.050$ & $38.10 \pm 0.044$ & $37.52 \pm 0.086$ \\
\hline FRCO 50 & 50 & $39.34 \pm 0.060$ & $39.3 \pm 0.083$ & $39.24 \pm 0.067$ & $38.92 \pm 0.037$ & $38.92 \pm 0.048$ & $38.60 \pm 0.070$ \\
\hline FRCO 100 & 100 & $39.4 \pm 0.034$ & $39.36 \pm 0.067$ & $39.36 \pm 0.040$ & $38.98 \pm 0.058$ & $38.62 \pm 0.020$ & $38.46 \pm 0.040$ \\
\hline FRCO 200 & 200 & $39.28 \pm 0.058$ & $39.22 \pm 0.131$ & $38.78 \pm 0.058$ & $38.52 \pm 0.177$ & $38.50 \pm 0.063$ & $38.38 \pm 0.058$ \\
\hline
\end{tabular}

${ }^{*} \mathrm{p}<0.05,{ }^{* *} \mathrm{p}<0.01$, compared with control group (ANOVA followed by Dunnett's test). Where, $\mathrm{N}=5$ Mean \pm SEM $=$ Mean \pm Standard error of mean

Table 5: Effect of FRCO on pyrexia-induced by brewer's yeast in rats

\begin{tabular}{|c|c|c|c|c|c|c|c|}
\hline \multirow[t]{2}{*}{ Group } & \multirow[t]{2}{*}{ Dose mg/kg } & \multicolumn{6}{|c|}{ Difference in temperature $\left({ }^{\circ} \mathrm{C}\right)($ Mean \pm SEM) } \\
\hline & & $1 \mathrm{~h}$ & $2 \mathrm{~h}$ & $3 \mathrm{~h}$ & $4 h$ & $5 \mathrm{~h}$ & $6 \mathrm{~h}$ \\
\hline Vehicle & - & $0.46 \pm 0.04$ & $0.54 \pm 0.024$ & $0.6 \pm 0.04$ & $0.6 \pm 0.031$ & $0.54 \pm 0.050$ & $0.62 \pm 0.037$ \\
\hline Std. (PARA) & 150 & $2.22 \pm 0.142$ & $1.62 \pm 0.058^{* *}$ & $1.52 \pm 0.080 * *$ & $0.98 \pm 0.080^{* *}$ & $0.94 \pm 0.060^{* *}$ & $40.52 \pm 0.050^{* *}$ \\
\hline FRCO 50 & 50 & $2.24 \pm 0.040$ & $2.36 \pm 0.02$ & $1.76 \pm 0.024$ & $1.82 \pm 0.037$ & $1.74 \pm 0.037 *$ & $1.5 \pm 0.031^{* *}$ \\
\hline FRCO 100 & 100 & $2.18 \pm 0.037$ & $2.3 \pm 0.031$ & $2.16 \pm 0.024$ & $2.14 \pm 0.024^{*}$ & $1.4 \pm 0.031^{* *}$ & $1.22 \pm 0.037^{* *}$ \\
\hline FRCO 200 & 200 & $2.26 \pm 0.040$ & $2.3 \pm 0.031$ & $1.5 \pm 0.158^{*}$ & $1.76 \pm 0.024^{* *}$ & $1.46 \pm 0.024^{* *}$ & $0.76 \pm 0.024^{* *}$ \\
\hline
\end{tabular}

${ }^{*} \mathrm{p}<0.05,{ }^{* *} \mathrm{p}<0.01$, compared with control group (ANOVA followed by Dunnett's test). Where, $\mathrm{N}=5$ Mean \pm SEM = Mean \pm Standard error of mean. FRCO: Flavonoid-rich fraction of C. obtusifolia Linn. 


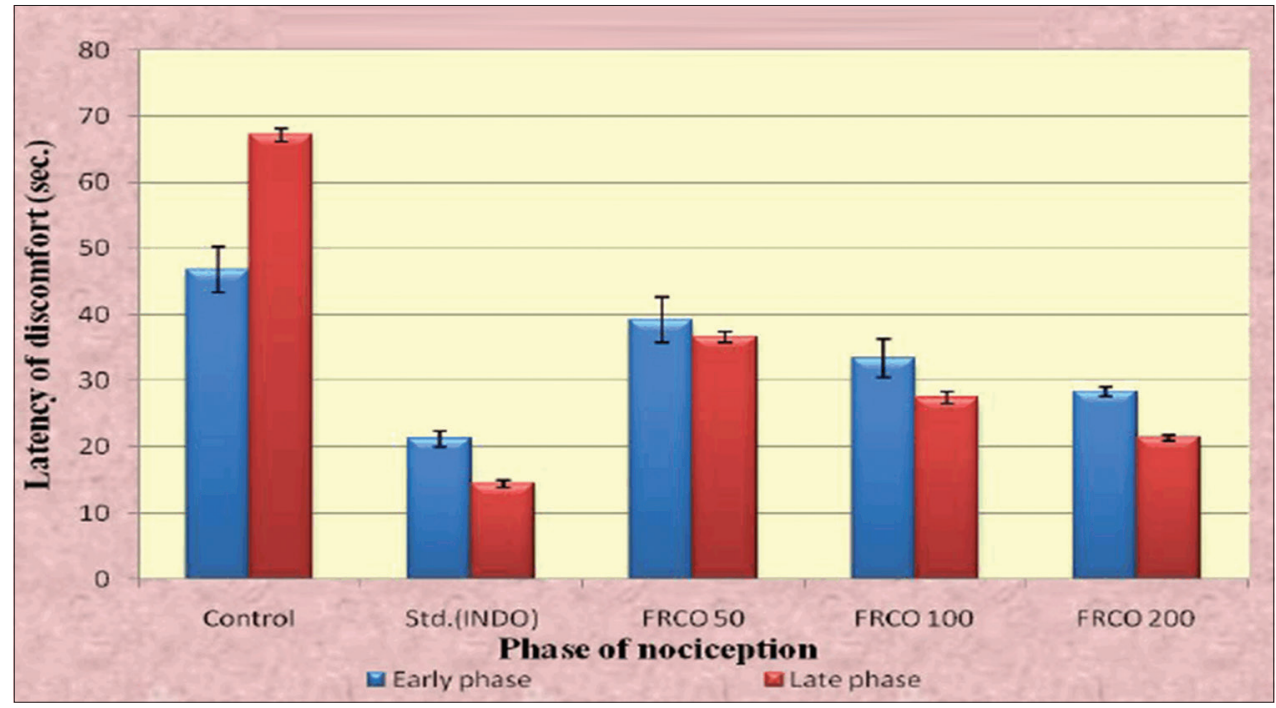

Fig. 5: Effects of FRCO on formalin test method. ${ }^{*} \mathbf{p}<0.05,{ }^{* *} p<0.01$, compared with the control group (ANOVA followed by Dunnett's test). Where, $\mathrm{N}=5$ Mean \pm SEM $=$ Mean \pm Standard error of mean

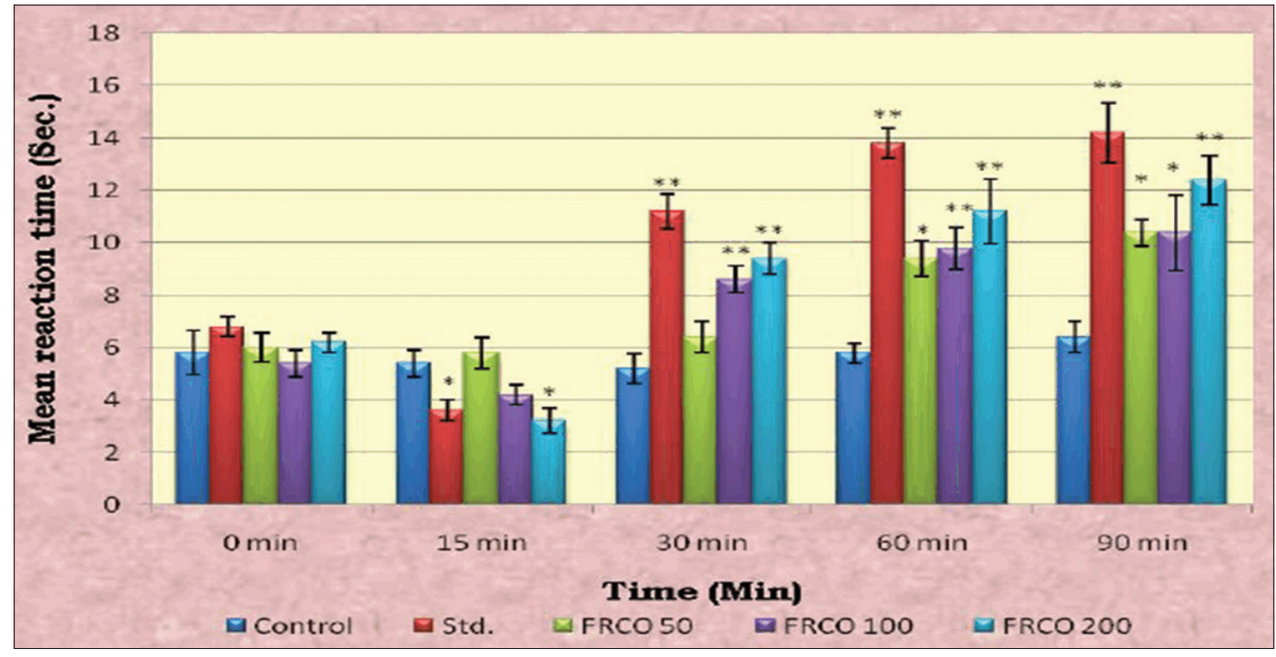

Fig. 6: Effect of FRCO on tail-flick test. ${ }^{*} \mathrm{p}<0.05,{ }^{* *} \mathrm{p}<0.01$, compared with the control group (ANOVA followed by Dunnett's test). Where, $\mathrm{N}=5$ Mean \pm SEM $=$ Mean \pm Standard error of mean

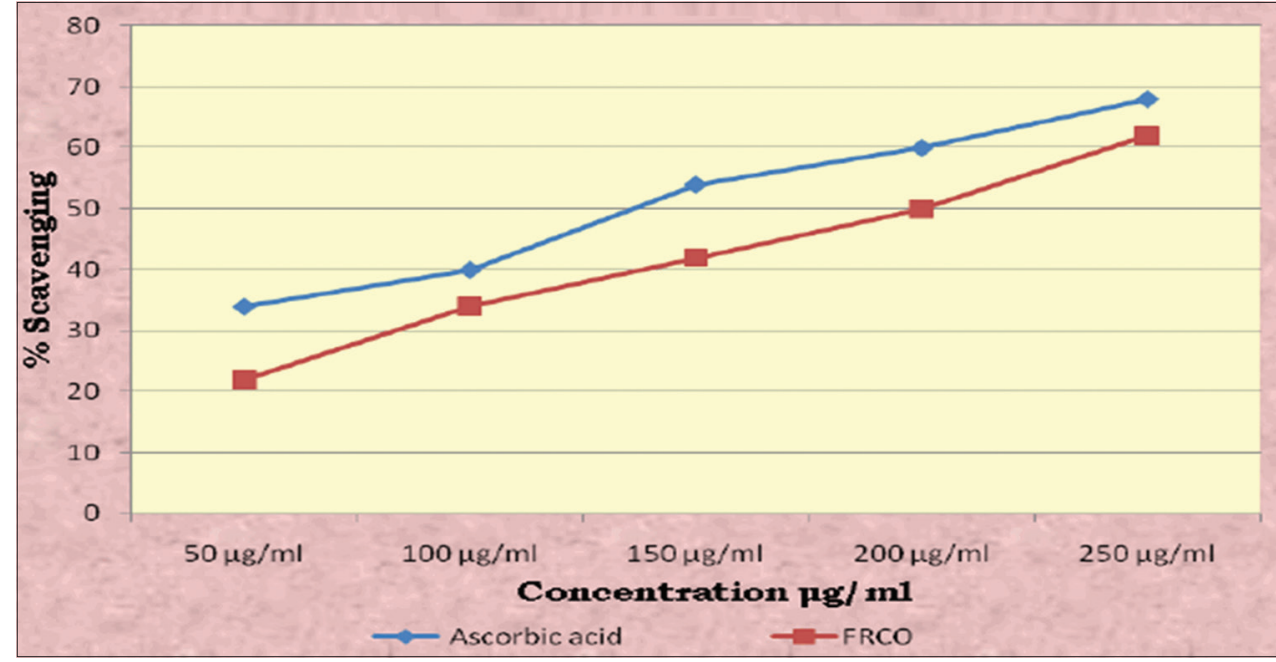

Fig. 7: Effect of FRCO in DPPH free radical scavenging assay 


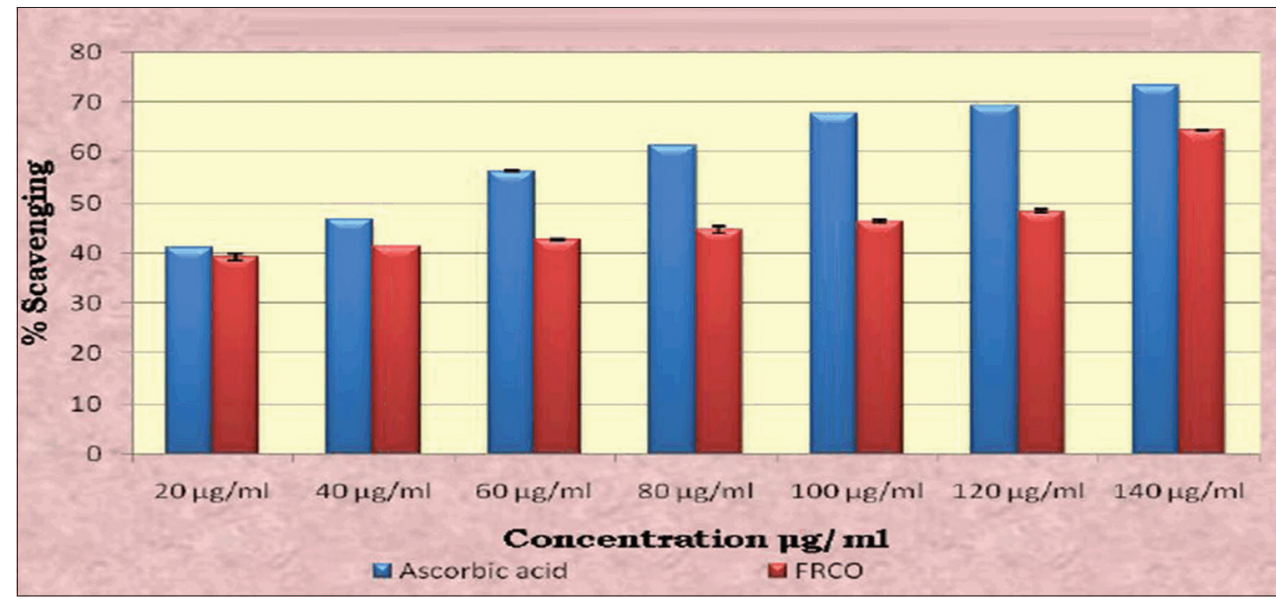

Fig. 8: Effect of FRCO in hydrogen peroxide assay

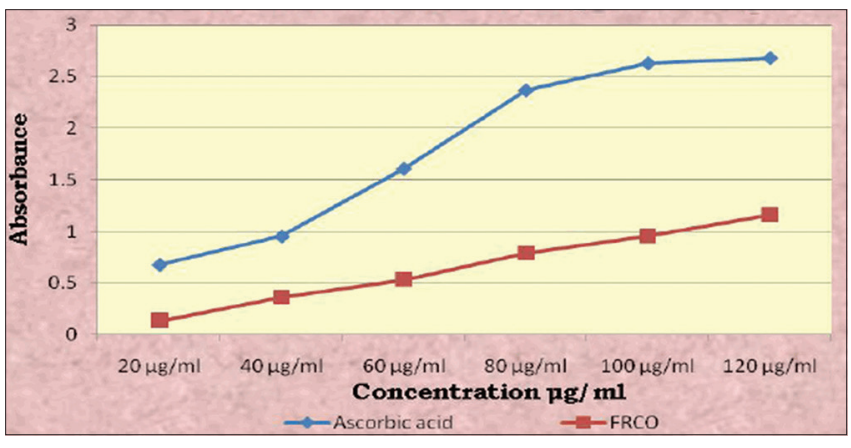

Fig. 9: Effect of FRCO in reducing power assay

Table 6: Effect of FRCO in DPPH free radical scavenging assay

\begin{tabular}{lllll}
\hline $\begin{array}{l}\text { Concentration } \\
\boldsymbol{\mu g} / \mathbf{m l}\end{array}$ & $\begin{array}{l}\text { \% Scavenging } \\
\text { ascorbic acid }\end{array}$ & $\begin{array}{l}\text { IC }_{\mathbf{5 0}} \\
\text { value }\end{array}$ & $\begin{array}{l}\text { \% Scavenging } \\
\text { FRCO }\end{array}$ & $\begin{array}{l}\text { IC }_{50} \\
\text { value }\end{array}$ \\
\hline $50 \mu \mathrm{g} / \mathrm{ml}$ & $34 \pm 2.000$ & 137 & $22 \pm 2.000$ & 200 \\
$100 \mu \mathrm{g} / \mathrm{ml}$ & $40 \pm 2.000$ & & $34 \pm 2.000$ & \\
$150 \mu \mathrm{g} / \mathrm{ml}$ & $54 \pm 3.464$ & & $42 \pm 3.464$ & \\
$200 \mu \mathrm{g} / \mathrm{ml}$ & $60 \pm 3.464$ & & $50 \pm 4.000$ & \\
$250 \mu \mathrm{g} / \mathrm{ml}$ & $68 \pm 2.000$ & & $62 \pm 3.464$ & \\
\hline
\end{tabular}

Table 7: Effect of FRCO in hydrogen peroxide assay

\begin{tabular}{llllll}
\hline $\begin{array}{l}\text { Concentration } \\
\boldsymbol{\mu g} / \mathbf{m l}\end{array}$ & \multicolumn{1}{l}{ Ascorbic acid } & & \multicolumn{2}{l}{ FRCO } & \\
\cline { 2 - 3 } \cline { 5 - 6 } & \% Scavenging & $\begin{array}{l}\text { IC }_{\text {50 }} \\
\text { value }\end{array}$ & & \% Scavenging & $\begin{array}{l}\text { IC }_{50} \\
\text { value }\end{array}$ \\
\hline 20 & $41.04 \pm 0.006$ & 48 & & $39.33 \pm 0.667$ & 127 \\
40 & $46.66 \pm 0.004$ & & $41.33 \pm 0.002$ & \\
60 & $56.33 \pm 0.002$ & & $42.66 \pm 0.333$ & \\
80 & $61.33 \pm 0.002$ & & $44.66 \pm 0.666$ & \\
100 & $67.66 \pm 0.0007$ & & $46.33 \pm 0.333$ & \\
120 & $69.33 \pm 0.006$ & & $48.33 \pm 0.333$ & \\
140 & $73.32 \pm 0.002$ & & $54.49 \pm 0.130$ & \\
\hline
\end{tabular}

FRCO: Flavonoid-rich fraction of C. obtusifolia Linn.

Table 8: Effect of FRCO in reducing power assay

\begin{tabular}{lll}
\hline Concentration $(\boldsymbol{\mu g} / \mathbf{m l})$ & $\begin{array}{l}\text { Absorbance of } \\
\text { Ascorbic acid }\end{array}$ & $\begin{array}{l}\text { Absorbance of } \\
\text { FRCO }\end{array}$ \\
\hline 20 & $0.674 \pm 0.0117$ & $0.1341 \pm 0.0020$ \\
40 & $0.9495 \pm 0.0038$ & $0.3632 \pm 0.0170$ \\
60 & $1.6078 \pm 0.0083$ & $0.5342 \pm 0.0021$ \\
80 & $2.3690 \pm 0.0248$ & $0.7930 \pm 0.0010$ \\
100 & $2.6314 \pm 0.0040$ & $0.9544 \pm 0.0010$ \\
120 & $2.6817 \pm 0.0014$ & $1.1616 \pm 0.0500$ \\
\hline
\end{tabular}

Effect of FRCO in hydrogen peroxide assay

In hydrogen peroxide assay, FRCO and ascorbic acid, showed significant radical scavenging activity at different concentrations $(20,40,60,80$, 100,120 , and $140 \mu \mathrm{g} / \mathrm{ml}$ ) in dose-dependent manner. IC $_{50}$ value was found to be 48 and $127 \mathrm{~g} / \mathrm{ml}$ for ascorbic acid and FRCO, respectively (Table 7 and Fig. 8).

\section{Reducing power assay}

In reducing power assay, FRCO and ascorbic acid showed significant radical power ability at different concentrations $(20,40,60,80,100$, and $120 \mu \mathrm{g} / \mathrm{ml}$ ) in dose-dependent manner (Table 8 and Fig. 9).

\section{CONCLUSION}

The $C$. obtusifolia plant belonging to Caesalpiniaceae family consisted of flavonoids as the major chemical constituents. These flavonoid-rich fractions were profound to have certain pharmacological potential. Thus, the present study reveals the anti-inflammatory, analgesic, antipyretic, and antioxidant potential of flavonoid-rich fractions of C. obtusifolia plant. The results of the in vitro assays and animal models conclude that $C$. obtusifolia has comparable pharmacological potentials.

\section{ACKNOWLEDGMENTS}

The authors gratefully acknowledge the support provided by Rajarshi Shahu College of Pharmacy, Buldana, Maharashtra, India.

\section{AUTHORS' CONTRIBUTIONS}

Dr. S.M Kewatkar and Dr. Vivek Paithankar contribution included designing and performing laboratory work, analyzing the results, and preparing the paper. Dr. Santosh Bhujbal, Dr. S.P. Jain, and Dr. D.H. Nagore contribution included data interpretation and identification of the compounds. All the authors have read the final manuscript and approved the submission.

\section{CONFLICTS OF INTEREST}

The authors declare that they have no conflicts of interest.

\section{AUTHORS FUNDING}

None.

\section{REFERENCES}

1. Steinmeyer J. Pharmacological basis for the therapy of pain and inflammation with nonsteroidal anti-inflammatory drugs. Arthritis Res 2000;2:379-85.

2. Chandrika M, Chellaram C. Efficacy of antioxidation and antiinflammation of the leaf extracts of Borreria hispida. Int J Pharm Pharm Sci 2016;8:369-72.

3. Sakat S, Juvekar AR, Gambhire MN. In vitro antioxidant and anti- 
inflammatory activity of methanol extract of Oxalis corniculata Linn. Int J Pharm Pharm Sci 2010;2:146-55.

4. Hatano $T$, Uebayashi H, Ito H, Shiota S, Tsuchiya T, Yoshida T. Phenolic constituents of Cassia seeds and antibacterial effect of some naphthalenes and anthraquinones on methicillin-resistant Staphylococcus aureus. Chem Pharm Bull (Tokyo) 1999;47:1121-7.

5. Al-Meshal IA, Tariq M, Parmar NS, Ageel AM. Anti-inflammatory activity of the flavonoid fraction of khat (Catha edulis Forsk). Agents Actions 1986;17:379-80.

6. Cibin TR, Srinivas G, Devi DG, Srinivas P, Lija Y, Abraham A. Antioxidant and antiproliferative effects of flavonoids from Emilia sonchifolia Linn on human cancer cells. Int J Pharm 2006;2:520-4.

7. Castardo JC, Prudente AS, Ferreira J, Guimarães CL, Monache FD, Filho VC, et al. Anti-inflammatory effects of hydroalcoholic extract and two biflavonoids from Garcinia gardneriana leaves in mouse paw oedema. J Ethnopharmacol 2008;118:405-11.

8. Organisation for Economic Co-operation and Development. OECD Guideline for Testing Of Chemicals. Acute Oral Toxicity-acute Toxic Class Method Adopted. France: Organisation for Economic Cooperation and Development; 2001;1:1-14.

9. Zeashan H, Amresh G, Rao CV, Singh S. Antinociceptive activity of Amaranthus spinosus in experimental animals. J Ethnopharmacol 2009; 122:492-6.

10. Xie F, Zhang M, Zhang CF, Wang ZT, Yu BY, Kou JP. Anti-inflammatory and analgesic activities of ethanolic extract and two limonoids from Melia toosendan fruit. J Ethnopharmacol 2008;117:463-6.

11. Zhang L, Hu JJ, Lin JW, Fang WS, Du GH. Anti-inflammatory and analgesic effects of ethanol and aqueous extracts of Pterocephalus hookeri (CB Clarke) Hoeck. J Ethnopharm 2009;123:510-4.

12. Whittle BA. The use of changes in capillary permeability in mice to distinguish between narcotic and nonnarcotic alalgesics. Br J Pharmacol
Chemother 1964;22:246-53

13. Arumugam P, Priya NG, Subathra M, Ramesh A. Anti-inflammatory activity of four solvent fractions of ethanol extract of Mentha spicata L. investigated on acute and chronic inflammation induced rats. Environ Toxicol Pharmacol 2008;26:92-5.

14. Mahmoudi M, Morteza-Semnani K, Mojra E. Anti-inflammatory and antinociceptive activity of Thymus pubescens extract. Fitoterapia 2008; $79: 361-5$

15. Singh A, Malhotra S, Subban R. Anti-inflammatory and analgesic agents from Indian medicinal plants. Int J Integr Bio 2008;3:57-72.

16. Jyothi G, Carey WM, Kumar RB, Mohan KG. Antinociceptive and antiinflammatory activity of methanolic extract of leaves of Shorea busta. Pharmacologyonline 2008;1:9-19.

17. Roldão Ede F, Witaicenis A, Seito LN, Hiruma-Lima CA, Di Stasi LC, Evaluation of the antiulcerogenic and analgesic activities of Cordia verbenacea DC. (Boraginaceae). J Ethnopharmacol 2008;119:94-8.

18. Lompo M, Guissou I, Dubois J, Dehaye JP, Ouédraogo A, Traore A, et al. Mechanism of the anti-inflammatory activity of Khaya senegalensis A. Juss. (Meliaceae). Int J Pharmacol 2007;3:137-42.

19. Devi BP, Boominathan R, Mandal SC. Evaluation of antipyretic potential of Cleome viscosa Linn. (Capparidaceae) extract in rats. J Ethnopharmacol 2003;87:11-3.

20. Panovska TK, Kulevanova S. Effect of some Teucrium species (Lamiaceae) on lipid peroxidation in rat liver microsomes. Fresenius Environ Bull 2005;14:957-9.

21. Shabrina RI, Elya BE, Noviani AR. Antioxidant activities of fractions from ethyl acetate extracts of Garcinia fruticosa lauterb leaves. Int J Appl Pharm 2018;10:44-50.

22. Usha B, Pushpalatha KC. In vitro antioxidant activity and phytochemical screening of leaf extracts of Grewia heterotricha mast. Int J Curr Pharm Res 2016;8:68-72. 